\title{
Pemberian makanan pendamping ASI (MP-ASI) dengan status gizi pada bayi usia 6-12 bulan
}

\author{
Linawati Novikasari ${ }^{1}$, Hardono $^{2}$, Heru Sapto Adi ${ }^{3 *}$ \\ 1Program Studi Ilmu Keperawatan Universitas Malahayati Bandar Lampung. \\ Email : lina.novika@yahoo.com \\ 2Program Studi llmu Keperawatan Universitas Aisyah Pringsewu, Lampung. \\ Email: hardonoaisyah2009@gmail.com \\ 3Puskesmas Bakung TBB Bandar Lampung. *Email : herusaptoadi27@gmail.com
}

\author{
Abstract \\ Complementary foods on infant breast milk intake and nutrition status \\ in infants 6 to 12 months old
}

Background: Based on pre-survey data for January 2019 in the Karang City Health Center for 30 infants aged 612 months, 12 infants (40\%) had normal nutritional status, and 18 infants $(60 \%)$ with undernourished status, based on data from interviews with people parents who have children aged 6-12 months with poor nutritional status, 10 mothers (55.5\%) said they did not know about the importance of giving MP-ASI such as the right time in giving MP-ASI, food menu for MP-ASI, and the portion MP-ASI for babies, and 8 mothers (44.5\%) said they only gave formula milk as a substitute for breast milk.

Purpose: Knowing to the relationship of complementary feeding (MP-ASI) with nutritional status in infants aged 6-12 months in the working area of Karang Bandar Lampung Health Center in 2019.

Method: Quantitative research type. Analytic survey research design with cross sectional design. The population of all mothers who have infants aged 6-12 months in the working area of Karang Bandar Lampung Health Center in 2019 amounted to 86 respondents, a sample of 86 respondents. The sampling technique used is total sampling. Chi-square test data analysis.

Results: Known in the working area of Karang Bandar Lampung Health Center in 2019, there were 45 respondents given MP-ASI well, 27 respondents $(60.0 \%)$ had good nutrition and 18 respondents $(40.0 \%)$ had poor nutrition, while there were 41 respondents given MP-ASI are not good, 10 respondents (24.4\%) have good nutrition and 31 respondents $(75.6 \%)$ have poor nutrition. Statistical test results, obtained p-value 0.002 or $p$ value $<0.05$

Conclusion: There is a relationship between complementary feeding (MP-ASI) with nutritional status in infants aged 6-12 months in the working area of Karang Bandar Lampung Health Center in 2019 with a p-value of 0.002. It is expected that the Puskesmas will be able to make a list of MP-ASI gift menus and provide infrastructure facilities on the MP-ASI menu according to the baby's needs.

\section{Keywords: Complementary foods; Breast milk; Nutritional status; Infants 6 to 12 months old}

Pendahuluan: Berdasarkan data prasurvey bulan Januari 2019 Di Puskesmas Kota Karang terhadap 30 bayi yang berusia $6-12$ bulan, diketahui 12 bayi (40\%) status gizi normal, dan 18 bayi $(60 \%)$ dengan status gizi kurang, berdasarkan data wawancara terhadap orang tua yang mempunyai anak usia 6-12 bulan dengan status gizi kurang, $10 \mathrm{ibu}(55,5 \%)$ mengatakan kurang mengetahui tentang pentingnya pemberian MP-ASI seperti waktu yang tepat dalam pemberian MP-ASI, menu makanan untuk MP-ASI, serta porsi MP-ASI untuk bayi, dan 8 ibu $(44,5 \%)$ mengatakan hanya memberikan susu formula sebagai pengganti ASI.

Tujuan: Diketahui hubungan pemberian makanan pendamping ASI (MP-ASI) dengan status gizi Pada Bayi usia 6-12 bulan Di Wilayah Kerja Puskesmas Kota Karang Bandar Lampung Tahun 2019. 
Pemberian makanan pendamping ASI (MP-ASI) dengan status gizi pada bayi usia 6-12 bulan

Metode: Jenis penelitian kuantitatif. Rancangan penelitian survey analitik dengan desain cross sectional. Populasi seluruh ibu yang mempunyai Bayi usia 6-12 bulan yang berada di Wilayah Kerja Puskesmas Kota Karang Bandar Lampung Tahun 2019 berjumlah 86 responden, Sampel 86 responden. Teknik sampling yang digunakan total sampling. Analisa data uji chi-square.

Hasil: Diketahui bahwa di wilayah kerja Puskesmas Kota Karang Bandar Lampung Tahun 2019, terdapat 45 responden yang diberikan MP-ASI dengan baik, 27 responden (60,0\%) mengalami gizi baik dan 18 responden $(40,0 \%)$ mengalami gizi kurang baik, sedangkan terdapat 41 responden yang diberikan MP-ASI kurang baik, 10 responden $(24,4 \%)$ mengalami gizi baik dan 31 responden $(75,6 \%)$ mengalami gizi kurang baik. Berdasarkan hasil uji statistik, didapatkan $p$-value 0,002 atau $p$-value $<0,05$.

Simpulan: Ada hubungan pemberian makanan pendamping ASI (MP-ASI) dengan status gizi pada bayi usia 612 bulan Di Wilayah Kerja Puskesmas Kota Karang Bandar Lampung Tahun 2019 dengan p-value 0,002. Diharapkan kepada pihak Puskesmas agar dapat membuat daftar menu pemberian MP-ASI dan menyediakan fasilitas sarana prasarana tentang menu MP-ASI sesuai dengan kebutuhan bayi.

\section{Kata Kunci: Makanan pendamping ASI (MP-ASI); Status gizi; Bayi usia 6-12 bulan}

\section{PENDAHULUAN}

Masalah gizi adalah masalah kesehatan masyarakat yang penanggulangannya tidak dapat dilakukan dengan pendekatan medis dan pelayanan kesehatan saja. Masalah gizi disamping merupakan sindroma kemiskinan yang erat kaitannya dengan masalah ketahanan pangan tingkat rumah tangga juga menyangkut aspek pengetahuan dan perilaku yang kurang mendukung pola hidup sehat (Sulistyoningsih, 2011).

Gizi merupakan salah satu factor yang menentukan keberhaslan untuk mencapai tumbuh kembang optimal pada masa bayi. Periode emas pertumbuhan memerlukan dukungan gizi yang tepat. Kekurangan gizi yang terjadi pada awal kehidupan dapat mengakibatkan terjadinya growth faltering (gagal tumbuh) menjadi anak yang lebih pendek dari nrmal. Selain itu, kekurangan gizi dapat berpengaruh terhadap perkembangan kognitif, morbiditas dan mortalitas bayi, gizi yang baik akan mempercepat pemulihan dan mengurangi intensitas (kegawatan) penyakit infeksi pada bayi (Fikawati, Wahyuni, \& Syafiq, 2012). Status gizi Bayi dapat diukur dengan indeks berat badan per umur $(B B / U)$, tinggi badan per umur ( $\mathrm{TB} / \mathrm{U})$ dan berat badan per tinggi badan (BB/TB), persentase gizi buruk pada balita usia 0-59 bulan di Indonesia hasil PSG tahun 2015 yaitu persentase gizi buruk pada balita usia 0-59 bulan sebesar 2,85\% dan persentase gizi kurang sebesar 13,20\%. Pada tahun 2016 yaitu persentase gizi buruk pada balita usia 0-59 bulan sebesar $3,4 \%$ dan persentase gizi kurang sebesar $14,43 \%$, sedangkan PSG tahun 2017 balita usia 059 bulan yang mengalami gizi buruk adalah 3,8\%, dan persentase gizi kurang adalah $14 \%$. Provinsi dengan persentase tertinggi gizi buruk dan gizi kurang pada balita usia 0-59 bulan tahun 2017 adalah Nusa Tenggara Timur, sedangkan provinsi dengan persentase terendah adalah provinsi Bali (Kementerian Kesehatan Republik Indonesia, 2017).

Berdasarkan pemantauan status gizi (PSG) tahun 2017 yang diselenggarakan oleh Kementrian Kesehatan menyatakan bahwa persentase gizi buruk Di Provinsi Lampung tahun 2015 pada anak balita usia 0-59 bulan mencapai 2,10\% sedangkan balita usia $0-59$ bulan yang mengalami gizi kurang mencapai 14,12\%. Tahun 2016 status gizi buruk pada anak balita usia 0-59 bulan mencapai 3,00\% sedangkan balita usia 0-59 bulan yang mengalami gizi kurang mencapai $14,35 \%$, sedangkan tahun 2017 status gizi buruk pada anak balita usia 0-59 bulan mencapai 3,50\% sedangkan balita usia 0-59 bulan yang mengalami gizi kurang mencapai 15,00\% (Dinas Kesehatan Provinsi Lampung, 2017).

Kota Bandar Lampung merupakan salah satu Kota Di Provinsi Lampung dengan angka gizi buruk cukup tinggi, pada tahun 2014 angka gizi buruk mencapai 3,3\% dan pada tahun 2015 mencapai hingga 4,2\%, dan tahun 2016 angka gizi buruk mencapai $6,4 \%$. Faktor yang sangat mempengaruhi terjadinya gizi buruk $\mathrm{Di}$ Kota Bandar Lampung adalah kurangnya persentase

\footnotetext{
Linawati Novikasari ' Program Studi llmu Keperawatan Universitas Malahayati Bandar Lampung.

Email : lina.novika@yahoo.com

Hardono ${ }^{2}$ Program Studi llmu Keperawatan Universitas Aisyah Pringsewu, Lampung.

Email: hardonoaisyah2009@gmail.com

Heru Sapto Adi ${ }^{3}$ Puskesmas Bakung TBB Bandar Lampung. *Email : herusaptoadi27@gmail.com
} 
cakupan pemberian MP-ASI pada bayi usia 6-12 bulan (Dinas Kesehatan Provinsi Lampung, 2016). Balita bawah garis merah merupakan salah satu alat skrining pencegahan kejadian status gizi buruk. Dengan pemantauan pertumbuhan balita terutama BGM maka penyimpangan pertumbuhan bisa dicegah. Pada tahun 2016 angka kejadian BGM mencapai 0,28\% dan pada tahun 2017 terjadi penurunan sebesar 0,19\%. Di Puskesmas Kota Karang Jumlah BGM pada tahun 2017 sebanyak $14(0,80 \%)$ (Dinas Kesehatan Kota Bandar Lampung, 2017).

Permasalahan gizi masih menjadi masalah yang serius. Kekurangan gizi menjadi penyebab dari sepertiga kematian anak di dunia. Gizi buruk dan juga gizi lebih masih menjadi persoalan yang harus dihadapi. Masalah gizi adalah hal yang sangat penting dan mendasar dari kehidupan manusia Kekurangan gizi selain dapat menimbulkan masalah kesehatan (morbiditas, mortalitas dan disabilitas), juga menurunkan kualitas sumber daya manusia (SDM) suatu bangsa. Dalam skala yang lebih luas, kekurangan gizi dapat menjadi ancaman bagi ketahanan dan kelangsungan hidup suatu bangsa. Salah satu faktor yang mempengaruhi status gizi pada bayi salah satunya berasal dari faktor ibu, dengan pendidikan ibu yang rendah, status pekerjaan serta tingkat pengetahuan yang kurang, maka ibu kurang mengetahui tentang pentingnya pemberian MP-ASI pada bayi (Proverawati \& Rahmawati, 2010).

Makanan Pendamping ASI (MP-ASI) adalah makanan atau minuman yang mengandung zat gizi, diberikan kepada bayi atau anak usia 6-24 bulan guna memenuhi kebutuhan gizi selain dari ASI. MP-ASI berupa makanan padat atau cair yang diberikan secara bertahap sesuai dengan usia dan kemampuan pencernaan bayi. Pada usia 6-24 bulan ASI hanya menyediakan 1/2 kebutuhan gizi bayi. Dan pada usia 12-24 bulan ASI menyediakan $1 / 3$ dari kebutuhan gizinya. Sehingga MP-ASI harus diberikan pada saat bayi berusia 6 bulan (Fikawati, Wahyuni \& Syafiq, 2012).

Pada usia 6 bulan sampai dengan 24 bulan, merupakan masa rawan pertumbuhan bayilanak. periode ini dengan nama penyapihan (weaning) yang merupakan proses dimulainya pemberian makanan khusus selain ASI, berbentuk padat atau semi padat secara bertahap jenis, jumlah, frekuensi, maupun tekstur dan konsistensinya sampai seluruh kebutuhan nutrisi anak dipenuhi. Memulai pemberian makanan pendamping ASI (MP-ASI) pada saat yang tepat akan sangat bermanfaat bagi pemenuhaan kebutuhan nutrisi dan tumbuh kembang anak menurut (Varghese \& Susmitha, 2015; Sandy, 2018).

Pemberian MP-ASI sangat mempengaruhi status gizi pada bayi. Pemberian MP-ASI meliputi cara pemberian menu seimbang untuk bayi khususnya usia 6-12 bulan, jika perilaku ibu dalam pemberian MP ASI, baik dari segi ketepatan waktu, jenis makanan, maupun jumlah makanan sangat baik, maka gizi pada bayi akan terpenuhi dengan maksimal. Peran ibu dalam memberikan MP-ASI adalah mulai dari menentukan, memilih, mengolah sampai dengan menyajikan menu gizi sehari-hari untuk bayi (Adriani \& Wirjatmadi, 2016; Oktaviana, \& Nuzula, 2017).

Berdasarkan studi pendahuluan tentang hubungan pemberian MP-ASI terhadap status gizi pada bayi, menyebutkan bahwa rata-rata ibu kurang memperhatikan pemberian MP-ASI yag diberikan pada bayi, banyak kesalahan yang dilakukan seperti porsi makanan yang tidak sesuai dengan kebutuhan bayi, jenis makanan yang terlalu berat yang diberikan kepada bayi, seperti telor goreng, tempe, tahu, serta makanan dewasa lainnya serta waktu yang tidak konsisten dalam memberikan MP-ASI, sehingga dengan perilaku pemberian MP-ASI yang kurang baik, maka akan berpengaruh terhadap status gizi pada bayi yang dilakukan oleh (Susilowati, 2016). Keadaan gizi kurang pada anak-anak mempunyai dampak pada kelambatan pertumbuhan dan perkemb angannya yang sulit disembuhkan. Oleh karena itu anak yang bergizi kurang tersebut kemampuannya untuk belajar dan bekerja serta bersikap akan lebih terbatas dibandingkan dengan anak yang normal (Santoso, 2009).

Kekurangan gizi pada umumya adalah menurunnya tingkat kesehatan masyarakat. Masalah gizi masyarakat pada dasarnya adalah masalah konsumsi makanan rakyat.Itulah program peningkatan gizi memerlukan pendekatan dan penggarapan diberbagai disiplin, baik teknis kesehatan, teknis produksi, sosial budaya dan lain sebagainya (Sudargo, Freitag, Kusmayanti, \& Rosiyani, 2018). Penilaian status gizi secara langsung dapat dibagi menjadi 4 penilaian yaitu

Linawati Novikasari ${ }^{1}$ Program Studi llmu Keperawatan Universitas Malahayati Bandar Lampung.

Email : lina.novika@yahoo.com

Hardono ${ }^{2}$ Program Studi llmu Keperawatan Universitas Aisyah Pringsewu, Lampung.

Email: hardonoaisyah2009@gmail.com

Heru Sapto Adi ${ }^{3}$ Puskesmas Bakung TBB Bandar Lampung. *Email : herusaptoadi27@gmail.com 
Pemberian makanan pendamping ASI (MP-ASI) dengan status gizi pada bayi usia 6-12 bulan

antropometri, klinis, biokimia, dan biofisik. Tetapi dalam penilaian ini menggunakan penilaian Antopometri (Yuniastuti, 2008). Beberapa tujuan gizi seimbang bagi Bayi, antara lain sebagai berikut: memenuhi kebutuhan nutrisi untuk petumbuhan dan perkembangan; memberikan nutrisi yang seimbang dan mencegah obesitas; memperoleh status gizi yang optimal dan pendidikan kesehatan antara lain tentang makanan tepat waktu, makanan beraneka ragam.

Keadaan gizi kurang tingkat berat pada masa bayi dan balita ditandai dengan dua macam sindrom yang jelas yaitu Kwashiorkor, karena kurang konsumsi protein dan Marasmus karena kurang konsums energi dan protein. Kwarsiorkor banyak dijumpai pada bayi dan balita pada keluarga berpenghasilan rendah, dan umumnya kurang sekali pendidikannya. Sedangkan Marasmus banyak terjadi pada bayi dibawah usia 1 tahun, yang disebabkan karena tidak mendapatkan ASI atau penggantinya (Kristiyanasari 2010; Yuniastuti, 2008).

Menurut Data Dinas Kota Bandar Lampung, terdapat 30 Puskesmas, untuk cakupan status gizi buruk, Puskesmas Kota Karang menempati posisi ke 2, dimana terdapat 10 besar Puskesmas dengan angka cakupan status gizi buruk yaitu Puskesmas Sukamaju mencapai 16 kasus $(1,23 \%)$, Puskesmas kota Karang mencapai 14 kasus $(0,80 \%)$, Puskesmas Palapa mencapai 14 kasus $(0,80 \%)$, Puskesmas Kedaton mencapai 10 kasus $(0,30 \%)$, Puskesmas Sumur Batu mencapai 8 kasus $(0,48 \%)$, Puskesmas Sukarame mencapai 7 kasus $(0,57 \%)$, Puskesmas Kupang Kota mencapai 6 kasus $(0,36 \%)$, Puskesmas Way Laga mencapai 3 kasus $(0,26 \%)$ dan Puskesmas Camping Raya mencapai 3 kasus $(0,25 \%)$ (Dinas kesehatan Kota Bandar Lampung, 2018).

Berdasarkan data prasurvey pada tanggal 1418 Januari 2019 Di Puskesmas Kota Karang terhadap 30 bayi yang berusia 6-12 bulan, diketahui hanya 12 bayi $(40 \%)$ yang mempunyai status gizi normal dengan kategori Z-score -2SD s.d +2SD, dan 18 bayi $(60 \%)$ mengalami status gizi buruk dengan kategori Z-score < - 2SD s.d < - -3SD, berdasarkan data wawancara terhadap orang tua yang mempunyai anak usia 6-12 bulan yang mempunyai status gizi buruk, dimana 10 ibu $(55,5 \%)$ diantaranya mengatakan kurang mengetahui tentang pentingnya pemberian MP-ASI seperti waktu yang tepat dalam pemberian MPASI, menu makanan untuk MP-ASI, serta porsi MP-ASI untuk bayi, dan 8 ibu $(44,5 \%)$ mengatakan hanya memberikan susu formula sebagai pengganti ASI.

Berdasarkan masalah diatas penulis tertarik untul mengambil penelitian dengan judul "Hubungan Pemberian Makanan Pendamping ASI (MP-ASI) Dengan Status Gizi Pada Bayi Usia 6-12 Bulan Di Wilayah Kerja Puskesmas Kota Karang Bandar Lampung Tahun 2019"

\section{METODE PENELITIAN}

Jenis penelitian kuantitatif dan rancangan menggunakan survei analitik dan pendekatan cross sectional. Teknik sampling menggunakan total sampling. Pengumpulan data dalam penelitian ini dengan lembar kuesioner dan lembar observasi, untuk Pemberian MP-ASI Mengisi lembar kuesioner yang terdiri dari 8 pernyataan yang berhubungan dengan pemberian MP-dengan option jawaban selalu (4), sering (3), kadangkadang (2) dan tidak pernah (1), maka akan didapatkan skor tertinggi adalah 32, sehingga apabila skor > 17,29 dikategorikan baik, jika skor < 17,29 maka dikategorikan buruk.

Sedangkan untuk mengetahui status gizi bayi menggunakan lembar observasi yang diukur melalalui penimbangan $B B$ dan $T B$, status Gizi Bayi Mengukur TB dan BB (Gizi Baik, jika Z score 2SD s.d + > 2SD) dan (Gizi Kurang - Gizi Buruk, jika Z score <-2 SD s.d < -3SD). Hasil uji validitas untuk kuesioner pemberian MP-ASI terhadap 20 responden, diketahui bahwa $r$ hitung untuk variabel pemberian MP-ASI adalah 0,571 - 0,844 dan $r$ tabel untuk 20 responden adalah 0,444 , sehingga $r$ hitung $>r$ tabel atau 0,571 - 0,844 >0,444, sehingga instrumen yang peneliti gunakan sudah teruji nilai validitasnya.

Dari hasil uji reliabilitas, maka dapat diketahui bahwa nilai $r$ hitung untuk variabel pemberian MPASI adalah $0,898-0,982$, sehingga $r$ hitung $>r$ table, atau 0,898 - 0,982 >0,444, dan diketahui nilai $r$ alpha untuk variabel pemberian MP-ASI adalah 0,951 , sehingga $r$ alpha $>r$ table atau 0,951 $>0,444$, sehingga instrument yang peneliti gunakan sudah teruji nilai reliabilitasnya.

\footnotetext{
Linawati Novikasari ' Program Studi llmu Keperawatan Universitas Malahayati Bandar Lampung. Email : lina.novika@yahoo.com

Hardono ${ }^{2}$ Program Studi llmu Keperawatan Universitas Aisyah Pringsewu, Lampung.

Email: hardonoaisyah2009@gmail.com

Heru Sapto Adi ${ }^{3}$ Puskesmas Bakung TBB Bandar Lampung. *Email : herusaptoadi27@gmail.com
} 
HASIL

Tabel 1. Distribusi Karakteristik Responden $\mathrm{N}=86$

\begin{tabular}{lcc}
\hline Variabel & Frekuensi (f) & Persentase (\%) \\
\hline Usia lbu & & \\
24-29 Tahun & 52 & 60,4 \\
30-37 Tahun & 34 & 39,6 \\
Pendidikan Ibu & & \\
SD & 17 & 19,8 \\
SMP & 26 & 30,2 \\
SMA & 34 & 39,5 \\
D3 & 6 & 7,0 \\
S1 & 3 & 3,5 \\
Pekerjaan Ibu & & \\
IRT & 34 & 39,5 \\
Buruh & 7 & 8,1 \\
Wiraswasta & 17 & 19,8 \\
Swasta & 19 & 22,1 \\
PNS & 9 & 10,5 \\
Pemberian MP-ASI & & \\
Baik & 45 & 52,3 \\
Buruk & 41 & 47,7 \\
Status Gizi Pada Bayi Usia & & \\
6-12 Bulan & & 43,0 \\
Baik & 37 & 57,0 \\
Buruk & 49 & \\
\hline
\end{tabular}

Berdasarkan tabel 1, diketahui sebagian besar usia ibu 24-29 Tahun yang berjumlah 52 responden $(60,4 \%)$, sebagain besar ibu berpendidikan SMA yang berjumlah 34 responden $(39,5 \%)$ dan sebagian besar responden mempunyai pekerjaan sebagai IRT yang berjumlah 34 responden $(39,5 \%)$. Sebagian besar responden memberikan MP-ASI dengan kategori baik yang berjumlah 45 responden (52,3\%), dan sebagian besar bayi mempunyai status gizi buruk berjumlah 49 bayi $(57,0 \%)$. 
Tabel 2. Hubungan Pemberian Makanan Pendamping ASI (MP-ASI) Dengan Status Gizi Pada Bayi Usia 6-12 Bulan $\mathrm{N}=86$

\begin{tabular}{|c|c|c|c|c|c|c|c|c|}
\hline \multirow{3}{*}{$\begin{array}{c}\text { Pemberian } \\
\text { MP-ASI }\end{array}$} & \multicolumn{4}{|c|}{ Status Gizi Bayi Usia 7-12 Bulan } & \multicolumn{2}{|c|}{ Total } & \multirow[t]{3}{*}{$p$-value } & \multirow[t]{3}{*}{ OR (Cl 95\%) } \\
\hline & \multicolumn{2}{|c|}{ Baik } & \multicolumn{2}{|c|}{ Buruk } & & & & \\
\hline & $\mathrm{n}$ & $\%$ & $\mathrm{n}$ & $\%$ & $\mathbf{N}$ & $\%$ & & \\
\hline Baik & 27 & 31,4 & 18 & 20,9 & 45 & 52,3 & 0,002 & 4,650 \\
\hline Buruk & 10 & 11,6 & 31 & 36,1 & 41 & 47,7 & & $\begin{array}{l}(1,836- \\
11,778)\end{array}$ \\
\hline Jumlah & 37 & 43,0 & 49 & 57,0 & 86 & 100,0 & & \\
\hline
\end{tabular}

Berdasarkan tabel 2, diketahui bahwa dari 45 responden yang diberikan MP-ASI dengan baik, terdapat 27 responden $(31,4 \%)$ mengalami gizi baik dan 18 responden $(20,9 \%)$ mengalami gizi kurang baik, sedangkan dari 41 responden yang diberikan MP-ASI kurang baik, terdapat 10 responden $(11,6 \%)$ mengalami gizi kategori baik dan 31 responden $(36,1 \%)$ mengalami gizi kategori buruk.

Berdasarkan hasil uji statistik, didapatkan pvalue 0,002 atau $p$-value $<0,05$ yang artinya terdapat hubungan antara pemberian makanan pendamping ASI (MP-ASI) dengan status gizi pada bayi usia 6-12 bulan Di Wilayah Kerja Puskesmas Kota Karang Bandar Lampung Tahun 2019 dengan nilai OR 4,650 yang artinya responden yang memberikan MP-ASI kurang baik akan mempunyai resiko 4,650 kali lebih besar bayi mengalami gizi kurang baik dibandingkan dengan yang memberikan MP-ASI dengan baik.

\section{PEMBAHASAN}

\section{Pemberian MP-ASI}

Berdasarkan hasil penelitian, sebagian besar responden memberikan MP-ASI dengan baik hanya berjumlah 45 responden (52,3\%), jumlahnya masih rendah dan masih belum sesuai anjuran Kementerian kesehatan dimana makanan pendamping ASI (MP-ASI) adalah makanan atau minuman yang mengandung zat gizi, diberikan kepada bayi atau anak usia 6-24 bulan guna memenuhi kebutuhan gizi selain dari ASI. MP-ASI berupa makanan padat atau cair yang diberikan secara bertahap sesuai dengan usia dan kemampuan pencernaan bayi.

Pada usia 6-24 bulan ASI hanya menyediakan 1/2 kebutuhan gizi bayi. Dan pada usia 12-24 bulan ASI menyediakan $1 / 3$ dari kebutuhan gizinya, sehingga MP-ASI harus diberikan pada saat bayi berusia 6 bulan karena pada usia 6 bulan sampai dengan 24 bulan, merupakan masa rawan pertumbuhan bayilanak (Varghese \& Susmitha, 2015).

Pada periode ini dengan nama penyapihan (weaning) yang merupakan proses dimulainya pemberian makanan khusus selain ASI, berbentuk padat atau semi padat secara bertahap jenis, jumlah, frekuensi, maupun tekstur dan konsistensinya sampai seluruh kebutuhan nutrisi anak dipenuhi. Memulai pemberian makanan pendamping ASI (MP-ASI) pada saat yang tepat akan sangat bermanfaat bagi pemenuhaan kebutuhan nutrisi dan tumbuh kembang anak. Penelitian sebelumnya di Wilayah Kerja Puskesmas Lesung Batu, Empat Lawang, mdidapatkan hasil uji hipotesa menunjukkan status gizi anak berhubungan dengan frekuensi MP-ASI ( $p$ value $<0,0001 ; O R=6,6$ ) riwayat penyakit infeksi ( $p$ value 0,$04 ; O R 3$ ). Sedangkan, usia pemberian MP-ASI pertama, tekstur makanan, variasi makanan dan porsi MP-ASI tidak berhubungan dengan status gizi anak usia 12-24 bulan (Widyawati, Febry, \& Destriatania, 2016).

\footnotetext{
Linawati Novikasari ' Program Studi llmu Keperawatan Universitas Malahayati Bandar Lampung.

Email : lina.novika@yahoo.com

Hardono ${ }^{2}$ Program Studi llmu Keperawatan Universitas Aisyah Pringsewu, Lampung.

Email: hardonoaisyah2009@gmail.com

Heru Sapto Adi ${ }^{3}$ Puskesmas Bakung TBB Bandar Lampung. *Email : herusaptoadi27@gmail.com
} 
Pemberian makanan pendamping ASI (MP-ASI) dengan status gizi pada bayi usia 6-12 bulan

Pemberian MP-ASI sangat mempengaruhi status gizi pada bayi dan pemberian MP-ASI meliputi cara pemberian menu seimbang untuk bayi khususnya usia 6-12 bulan, jika perilaku ibu dalam pemberian MP ASI, baik dari segi ketepatan waktu, jenis makanan, maupun jumlah makanan sangat baik, maka gizi pada bayi akan terpenuhi dengan maksimal. Peran ibu dalam memberikan MP-ASI adalah mulai dari menentukan, memilih, mengolah sampai dengan menyajikan menu gizi sehari-hari untuk bayi (Septiani, 2014).

Penelitian di Manado didapatkan 79 responden yang memiliki MP-ASI kategori baik sebanyak 57 responden (72.15\%), MP-ASI kategori buruk sebanyak 22 responden (27.84\%) (Datesfordate, Kundre, \& Rottie, 2017). Berdasarkan hasil penelitian diatas, maka dapat disimpulkan bahwa bayi yang sudah melewati usia 6 bulan wajib diberikan MP-ASI dengan tujuan agar status gizi bayi menjadi baik, pada saat dilakukan penelitian diketahui responden memberikan MP-ASI dengan kategori baik lebih banyak, hal ini di karenakan pengetahuan ibu yang baik tentang pentingnya pemberian MP-ASI, dan sebagian besar para ibu tidak bekerja sehingga memiliki waktu yang lebih banyak dalam mengurus bayinya, selain itu juga dikarenakan adanya dukungan keluarga dalam mengurus anak.

\section{Status Gizi}

Berdasarkan hasil penelitian, diketahui sebagian besar bayi mempunyai status gizi buruk berjumlah 49 bayi $(57,0 \%)$. Hasil penelitian ini sesuai kajian kementerian kesehatan bahwa permasalahan gizi masih menjadi masalah yang serius. Kekurangan gizi menjadi penyebab dari sepertiga kematian anak di dunia. Gizi buruk dan juga gizi lebih masih menjadi persoalan yang harus dihadapi. Masalah gizi adalah hal yang sangat penting dan mendasar dari kehidupan manusia, kekurangan gizi selain dapat menimbulkan masalah kesehatan (morbiditas, mortalitas dan disabilitas), juga menurunkan kualitas sumber daya manusia (SDM) suatu bangsa.

Dalam skala yang lebih luas, kekurangan gizi dapat menjadi ancaman bagi ketahanan dan kelangsungan hidup suatu bangsa. Salah satu faktor yang mempengaruhi status gizi pada bayi salah satunya berasal dari faktor ibu, dengan pendidikan ibu yang rendah, status pekerjaan serta tingkat pengetahuan yang kurang, maka ibu kurang mengetahui tentang pentingnya pemberian MP-ASI pada bayi.

Menurut Penelitian di Manado, menunjukan dari 79 responden, yang memiliki status gizi baik sebanyak 36 responden $(45,56 \%)$, Status gizi buruk sebanyak 43 responden $(54,43 \%)$ ( Datesfordate, Kundre, \& Rottie, 2017).

Berdasarkan hasil penelitian diatas, maka menurut peneliti kebutuhan bayi akan nutrisi sangat berpengaruh terhadap status gizi bayi, hal ini dibuktikan dengan hasil penelitian bahwa rata-rata bayi mengalami status gizi buruk lebih besar dibanding status gizi baik, hal ini dkarenakan faktor kurangnya asupan nutrisi dan makanan pendamping ASI yang diberikan oleh ibu, karena kurangnya informasi yang didapatkan oleh ibu tentang pentingnya MP-ASI dan kesibukan ibu dalam bekerja sehingga tidak cukup waktu ibu dalam mengurus anak.

\section{Hubungan Pemberian Makanan Pendamping ASI (MP-ASI) Dengan Status Gizi}

Berdasarkan hasil penelitian, diketahui dari 45 responden yang diberikan MP-ASI dengan baik, terdapat 27 responden $(31,4 \%)$ mengalami gizi baik dan 18 responden $(20,9 \%)$ mengalami gizi buruk, sedangkan dari 41 responden yang diberikan MP-ASI kategori buruk, terdapat 10 responden $(11,6 \%)$ mengalami gizi kategori baik dan 31 responden $(36,1 \%)$ mengalami gizi kategori buruk.

Berdasarkan hasil uji statistik, didapatkan $\mathrm{p}$ value 0,002 atau $p$-value $<0,05$ yang artinya terdapat hubungan pemberian makanan pendamping ASI (MP-ASI) dengan status gizi pada bayi usia 6-12 bulan dengan nilai OR 4,650 yang artinya responden yang memberikan MP-ASI buruk akan mempunyai peluang 4,650 kali lebih besar bayi mengalami gizi buruk dibandingkan dengan yang memberikan MP-ASI dengan baik.

Beberapa faktor yang mempengaruhi status gizi pada bayi, antara lain yaitu faktor umur dimana kebutuhan zat gizi pada orang dewasa berbeda dengan kebutuhan gizi pada anak batita karena pada masa batita terjadi pertumbuhan dan perkembangan yang sangat pesat. Semakin bertambah umur, kebutuhan zat gizi seseorang relatif lebih rendah, faktor aktivitas yang dilakukan sehari-hari.

\footnotetext{
Linawati Novikasari ' Program Studi llmu Keperawatan Universitas Malahayati Bandar Lampung.

Email : lina.novika@yahoo.com

Hardono ${ }^{2}$ Program Studi llmu Keperawatan Universitas Aisyah Pringsewu, Lampung.

Email: hardonoaisyah2009@gmail.com

Heru Sapto Adi ${ }^{3}$ Puskesmas Bakung TBB Bandar Lampung. *Email : herusaptoadi27@gmail.com
} 
Pemberian makanan pendamping ASI (MP-ASI) dengan status gizi pada bayi usia 6-12 bulan

Semakin berat aktivitas yang dilakukan, kebutuhan zat gizi makin tinggi, terutama energi, faktor jenis kelamin antara laki-laki dan perempuan terutama pada usia dewasa. Perbedaan ini terutama disebabkan oleh jaringan penyusun tubuh dan jenis aktivitasnya, faktor daerah tempat tinggal didaerah pegunungan yang dingin membutuhkan kecukupan energi yang lebih tinggi dibandingkan dengan yang tinggal didaerah pesisir yang panas, dan faktor pemberian MP-ASI yang tepat dan benar dapat dimulai pada usia 6 bulan, karena pada usia ini bayi memulai gerakan mengunyah serta menggerakan rahang ke atas dan ke bawah serta sudah mampu menggenggam dengan telapak tangan (Adriani, \& Wirjatmadi, 2016).

Keberhasilan pemberian MP-ASI ini di pengaruhi juga oleh perkembangan fungsi system syaraf, saluran cerna dan ginjal bayi. Status gizi yang baik pada bayi dapat terjadi jika tubuh dalam keadaan normal (sehat) dan mengkonsumsi makanan dengan kebutuhan akan zat-zat gizinya terjamin. Gizi baik dintandai dengan pertumbuhan berat badan anak sesuai dengan umur.

Apabila pertumbuhan berat badan berlebih dari umur anak, maka dikatakan anak mengalami gizi lebih. Bayi juga dapat mengalami gizi kurang apabila tidak memperoleh cukup makanan atau konsumsi energy dan protein yang kurang dari makanan sehari-hari dan pertumbuhan kritis.

Hasil penelitian ini peneliti berasumsi bahwa status gizi bayi dilihat berat badan bayi, dan ibu yang memberikan pola makan kepada bayi dan tekstur makan bayi yang mengandung zat gizi sehingga cakupan makanan yang di peroleh bayi menjadi lebih baik.

Penelitian di Manado, berdasarkan hasil uji statistic chi square di peroleh nilai $p=0.000$ hal ini berarti bahwa $p$ lebih besar dari $a(p=0,000>a=$ 0,05), dan berarti dapat dikatakan Hipotesis $\mathrm{H} 1$ diterima dan $\mathrm{HO}$ di tolak. Hal ini menunjukkan bahwa terdapat hubungan yang signifikan antara pemberian MP-ASI dengan status gizi bayi pada usia 6- 12 bulan di wilayah kerja puskesmas bahu manado (Datesfordate, Kundre, \& Rottie, 2017).

Berdasarkan hasil penelitian diatas, maka menurut peneliti semakin buruk dalam memberikan MP-ASI, maka berisiko tinggi status gizi bayi menjadi buruk juga, berdasarkan hasil penelitian diketahui terdapat bayi yang diberikan MP-ASI dengan baik, namun masih ada bayi yang mengalami gizi kategori buruk yaitu 18 responden $(20,9 \%)$, hal ini dikarenakan faktor usia pada bayi yaitu yang memiliki umur 6-7 bulan dimana membutuhkan kebutuhan zat gizi lebih besar dibanding bayi yang berumur 10-12 bulan, jenis kelamin responden adalah bayi laki-laki dimana membutuhkan lebih banyak zat gizi karena memiliki aktivitas yang lebih, tempat tinggal responden yang dingin, dan kondisi kebutuhan gizi saat ibu hamil kurang sehingga mempengaruhi tumbuh kembang janin dan produksi ASI tidak cukup, sedangkan terdapat bayi yang diberikan MP-ASI buruk, namun masih ada bayi yang mempunyai status gizi baik yaitu 10 responden $(11,6 \%)$, hal ini dikarenakan faktor jenis kelamin pada responden bayi perempuan, kondisi kebutuhan gizi ibu saat hamil baik sehingga produksi ASI cukup saat bayi lahir selain itu dukungan keluarga serta lingkungan sekitar yang selalu memberikan motivasi kepada ibu untuk memberikan asuhan dan perawatan kepada bayi

\section{SIMPULAN}

Berdasarkan hasil penelitian diatas, maka kesimpulan dalam penelitian ini, sebagian besar responden memberikan MP-ASI dengan baik yang berjumlah 45 responden $(52,3 \%)$, sebagian besar bayi mempunyai status gizi buruk berjumlah 49 bayi $(57,0 \%)$. Ada hubungan pemberian makanan pendamping ASI (MP-ASI) dengan status gizi pada bayi usia 6-12 bulan Di Wilayah Kerja Puskesmas Kota Karang Bandar Lampung Tahun 2019 dengan p-value 0,002.

\section{SARAN}

Puskesmas sebagai institusi pelayanan terdepan supaya lebih proaktif memberikan perhatian pada para ibu yang mempunyai bayi usia 7-12 bulan, agar bayinya tercukupi status gizinya. Pada peneliti selanjutnya agar dapat melakukan penelitian lebih lanjut tentang faktorfaktor lain yang mempengaruhi status gizi pada bayi usia 7-12 bulan, dengan begitu semua permasalah gizi pada bayi akan diketahui dan akan didapatkan solusinya.

\footnotetext{
Linawati Novikasari ' Program Studi llmu Keperawatan Universitas Malahayati Bandar Lampung. Email : lina.novika@yahoo.com

Hardono $^{2}$ Program Studi llmu Keperawatan Universitas Aisyah Pringsewu, Lampung.

Email: hardonoaisyah2009@gmail.com

Heru Sapto Adi ${ }^{3}$ Puskesmas Bakung TBB Bandar Lampung. *Email : herusaptoadi27@gmail.com
} 


\section{DAFTAR PUSTAKA}

Adriani, M., \& Wirjatmadi, B. (2016). Peranan gizi dalam siklus kehidupan. Jakarta: Kencana prenada media group.

Datesfordate, A. H., Kundre, R., \& Rottie, J. V. (2017). Hubungan Pemberian Makanan Pendamping Air Susu Ibu (MP-ASI) Dengan Status Gizi Bayi Pada Usia 6-12 Bulan Di Wilayah Kerja Puskesmas Bahu Manado. Jurnal Keperawatan, 5(2).

Dinas Kesehatan Kota Bandar Lampung.(2017). Profil Puskesmas Kota Karang Bandar Lampung tahun 2016

Dinas Kesehatan Provinsi Lampung. (2016). Data Prevalensi Kejadian Obesitas. Lampung: Dinas Kesehatan Lampung tahun 2015

Dinas Kesehatan Provinsi Lampung. (2017). Data Prevalensi Kejadian Obesitas. Lampung: Dinas Kesehatan Lampung tahun 2016

Fikawati, S., Wahyuni, D., \& Syafiq, A. (2012). Status gizi ibu hamil dan berat lahir bayi pada kelompok vegetarian. Makara kesehatan, 16(1), 29-35.

Kementerian Kesehatan Republik Indonesia. (2017). Data dan informasi profil kesehatan Indonesia 2016. Jakarta: Pusat Data dan Informasi Kementerian Kesehatan RI.

Kristiyanasari.(2010). Kebutuhan Gizi Pada Balita. Yogyakarta: Nuha Medika.

Oktaviana, M. N., \& Nuzula, F. (2017). Pola Pemberian Makanan Pendamping ASI (MPASI) Pada Bayi Kurang Gizi Usia 6-12 Bulan Di Wilayah Puskesmas Kalibaru Kulon Kabupaten Banyuwangi. Jurnal IImiah Kesehatan Rustida, 4(1), 415-423.
Proverawati, A., \& Rahmawati, E. (2010). Kapita selekta ASI dan menyusui. Yogyakarta: Nuha Medika.

Sandy, D. M. (2018). Hubungan tingkat pengetahuan ibu dan pendidikan dengan pemberian makanan pendamping asi di puskesmas 23 llir Palembang. Masker Medika, 6(2), 569-575.

Santoso, S. (2009). Panduan lengkap menguasai statistik dengan SPSS 17. Jakarta: PT Elex Media Komputindo.

Septiani, W. (2014). Hubungan Pemberian Makanan Pendamping Asi Dini dengan Status Gizi Bayi 0-11 Bulan di Puskesmas Bangko Rokan Hilir. Jurnal Kesehatan Komunitas, 2(4), 148-153.

Sudargo, T., Freitag, H., Kusmayanti, N. A., \& Rosiyani, F. (2018). Pola makan dan obesitas. UGM press.

Sulistyoningsih, H. (2011). Gizi untuk kesehatan ibu dan anak. Yogyakarta: Graha IImu.

Susilowati, K. (2016). Gizi dalam daur kehidupan. PT Refika Aditama: Bandung

Varghese, S., \& Susmitha, A. (2015). Textbook of Pediatric Nursing

Widyawati, W. W., Febry, F., \& Destriatania, S. (2016). Analisis Pemberian MP-ASI dengan Status Gizi pada Anak Usia 12-24 Bulan Di Wilayah Kerja Puskesmas Lesung Batu, Empat Lawang. Jurnal IImu Kesehatan Masyarakat, 7(2).

Yuniastuti, A. (2008). Gizi dankesehatan. Yogyakarta: Graha IImu, 95102.

\footnotetext{
Linawati Novikasari ' Program Studi llmu Keperawatan Universitas Malahayati Bandar Lampung. Email : lina.novika@yahoo.com

Hardono ${ }^{2}$ Program Studi llmu Keperawatan Universitas Aisyah Pringsewu, Lampung

Email: hardonoaisyah2009@gmail.com

Heru Sapto Adi ${ }^{3}$ Puskesmas Bakung TBB Bandar Lampung. *Email : herusaptoadi27@gmail.com
} 